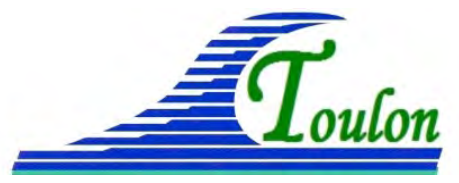

XIV èmes Journées Nationales Génie Côtier - Génie Civil

Toulon, 29 juin au $1^{\text {er }}$ juillet 2016

DOI:10.5150/jngcgc.2016.003 (C) Editions Paralia CFL

disponible en ligne - http://www.paralia.fr - available online

\title{
Swash hydrodynamic modelling using a tri-dimensional model: CROCO
}

\author{
Rachid BENSHILA ${ }^{1}$, Luis Pedro ALMEIDA ${ }^{2}$, \\ Patrick MARCHESIELLO ${ }^{2}$, Rafael ALMAR ${ }^{2}$
}

\section{CNRS, LEGOS, UMR6655 CNRS-CNES-IRD-UPMC,} 14 avenue Edouard Belin, 31400 Toulouse, France.

rachid.benshila@legos.obs-mip.fr

2. IRD, LEGOS, UMR6655 CNRS-CNES-IRD-UPMC,

14 avenue Edouard Belin, 31400 Toulouse, France.

pedro.almeida@legos.obs-mip.fr ; patrick.marchesiello@ird.fr ; rafael.almar@ird.fr

\begin{abstract}
:
The swash zone is one the most dynamic regions in the nearshore. During storms the beach response (erosion and recovery) is strongly controlled by the swash zone and for this reason it is crucial to acquire field data to and develop new modelling solutions to improve the forecast of the processes in this zone. New remote sensing techniques, such as 2D Lidar, that can measure swash hydro- and morphodynamics provide extremely valuable observations to develop and validate numerical models. In the present work a novel dataset of swash hydrodynamic observations (performed by a 2D Lidar) are used to test the performance of a new non-hydrostatic tri-dimensional numerical model (CROCO) to predict wave transformation and swash motions on a sandy beach with a low tide terrace (Nha Trang, Vietnam). An high resolution grid was setup, covering the entire swash zone and the inner surf zone, and 2 types of simulations were performed with energetic waves and mild wave conditions. Comparisons between CROCO and 2D Lidar indicate that despite some differences between individual waves characteristics (length of swash excursions and durations) in the overall the model show skills to predict extreme runup statistics (e.g., R2\% or R10\%) with very high level of accuracy, particularly during mild energetic wave conditions.
\end{abstract}

Keywords: Nearshore modelling, Swash zone dynamics, Wave resolving, Foreshore.

\section{Dataset}

A field experiment was undertaken between 26 November and 04 December 2015 at Nha Trang beach, a sandy beach located on a semi-closed bay on the South East of Vietnam (Figure 1). This medium-to-coarse sandy beach $\left(D_{50}=0.3 \mathrm{~mm}\right)$ has a fairly steep beach face slope ( 0.1) and a narrow ( $\sim 40 \mathrm{~m}$ ) alongshore uniform and flat ( 0.01) low tide terrace (LTT). A 2D Lidar (SICK LMS500) deployed on top of a metallic tower (Figure 1) to measure high frequency $(4 \mathrm{~Hz})$, and high resolution (average 
distance between points is about $10 \mathrm{~cm}$ ) swash zone hydrodynamics (swash position and depth) and morphological evolution along a cross-shore section of the beach.
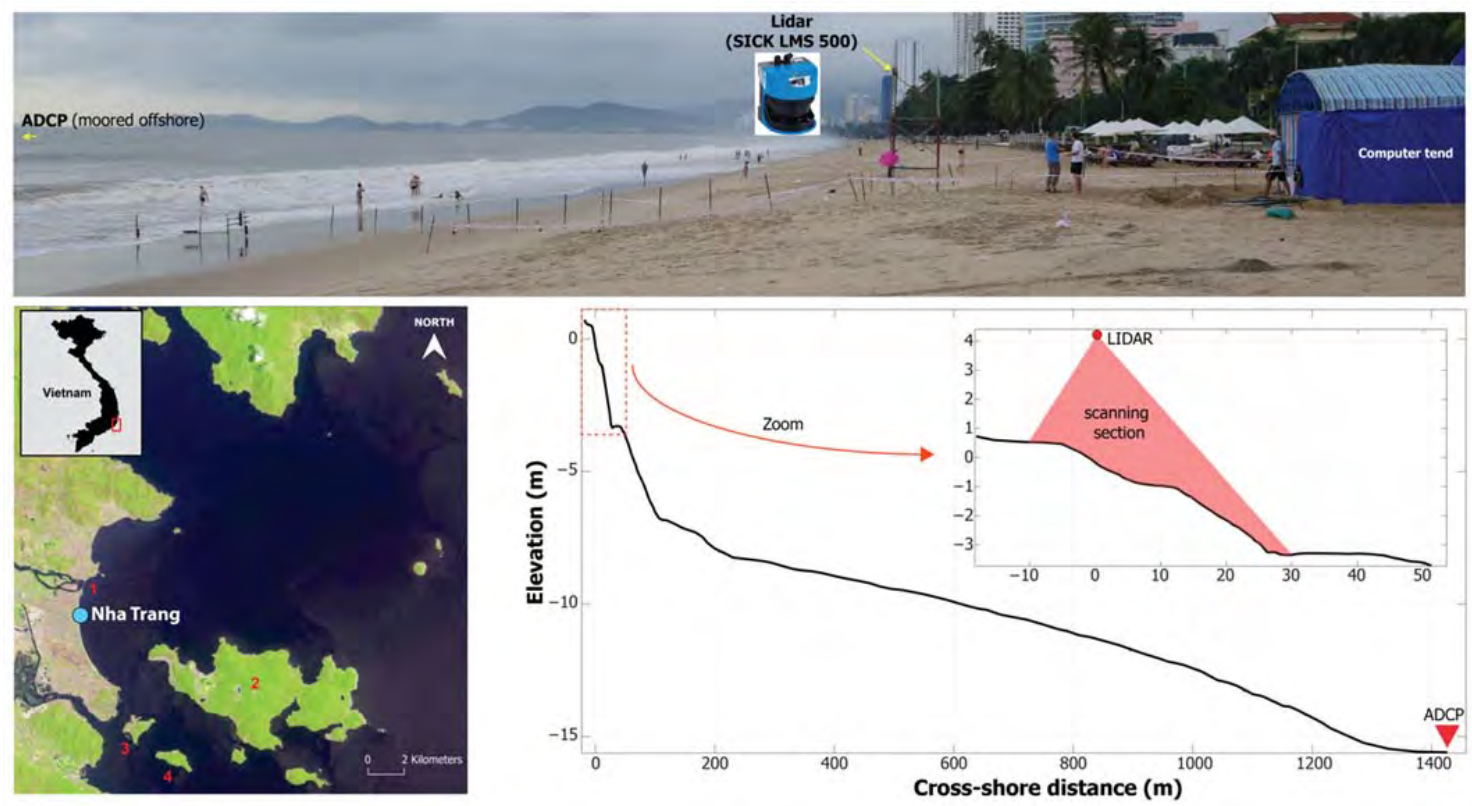

Figure 1. Location and data acquisition system.

\section{Circulation model framework}

\subsection{Description}

CROCO is the last evolution of ROMS-AGRIF model (PENVEN et al., 2006), part of the ROMS model. It has the particularity of having nesting capabilities and a nonhydrostatic option (not used here). Initially developed for basin scale modelling (O10 $\mathrm{km}$ ), its use has recently been extended and assessed to nearshore processes resolutions (O10 m, MARCHESIELLO et al., 2015) with phase averaged wave forcing. We propose here to go one range further in resolving decimetre scales processes and solving explicit waves.

CROCO is a three-dimensional, free surface, terrain-following numerical circulation model that solves finite-difference approximations of the Reynolds averaged NavierStokes (RANS) equations using the hydrostatic and Boussinesq assumptions (CHASSIGNET et al., 2000; HAIDVOGEL et al., 2000) with a split-explicit time stepping algorithm (SHCHEPETKIN \& MCWILLIAMS, 2005; HAIDVOGEL et al., 2008). It uses a horizontal curvilinear Arakawa $C$ grid and vertical stretched terrainfollowing coordinates. CROCO has a flexible structure that allows choices for many of the model components, including options for advection schemes (second order, third order, fourth order, and positive definite), turbulence submodels, and boundary conditions. It includes bottom and surface boundary layer submodels, air-sea fluxes, 


\section{XIV ${ }^{\text {èmes }}$ Journées Nationales Génie Côtier - Génie Civil \\ Toulon, 29 juin au $1^{\text {er }}$ juillet 2016}

surface drifters, a nutrient-phytoplankton-zooplankton model. Momentum, scalar advection, and diffusive processes are represented using transport equations. The density field is determined from an equation of state that accounts for temperature, salinity, and suspended-sediment concentrations. In this paper, the term constant refers to values that are time-invariant, and the term uniform refers to values that do not vary in space. The governing equations (1)-(4) are presented in flux form, in Cartesian horizontal coordinates and sigma vertical coordinates. For curvilinear grids, additional metric terms appear (HAIDVOGEL et al., 2000) that are not shown here. A complete list of variables is given in Table 1 . In the particular case of a $\mathrm{x}-\mathrm{z}$ section for a fluid with uniform density, the classical primitives equations become for the momentum:

$$
\begin{aligned}
& \frac{\partial\left(H_{z} u\right)}{\partial t}+\frac{\partial\left(u H_{z} u\right)}{\partial x}+\frac{\partial\left(\Omega H_{z} u\right)}{\partial s} \\
& =-\frac{H_{z}}{\rho_{0}} \frac{\partial p}{\partial x}-H_{z} g \frac{\partial \eta}{\partial x}-\frac{\partial}{\partial s}\left[\frac{\left(K_{M}+v\right)}{H_{z}} \frac{\partial u}{\partial s}\right]+\mathcal{F}_{u}+\mathcal{D}_{u} \\
& 0=-\frac{1}{\rho_{0}} \frac{\partial p}{\partial s}-\frac{g}{\rho_{0}} H_{z} \rho
\end{aligned}
$$

for the mass conservation:

$\frac{\partial \eta}{\partial t}+\frac{\partial\left(H\left({ }_{z} u\right)\right.}{\partial x}+\frac{\partial\left(H_{z} \Omega\right)}{\partial s}=0$

and for the tracer transport (if any):

$\frac{\partial\left(H_{z} C\right)}{\partial t}+\frac{\partial\left(u H_{z} C\right)}{\partial x}+\frac{\partial\left(\Omega H_{z} C\right)}{\partial s}=-\frac{\partial}{\partial s}\left[\frac{K_{\theta+v_{\theta}}}{H_{z}} \frac{\partial u v}{\partial s}\right]+C_{\text {source }}$

with $u, \Omega$ the velocity components in the $(x s)$ referential, $H_{z}$ the level thickness, $p$ the pressure, $\rho$ the density anomaly, $\rho_{0}$ the reference density, $g$ the gravity, $\eta$ the free surface elevation, $v$ the molecular viscosity, $K_{M}$ the vertical eddy viscosity, $\mathcal{F}_{u}$ and $\mathcal{D}_{u}$ the forcing terms and the horizontal.

\subsection{Model tests}

For swash modelling at Nha Trang we set up configuration corresponding to the observations presented in Figure 1, covering an extent of $30 \mathrm{~m}$, at $0.1 \mathrm{~m}$ resolution. The model is only forced at its offshore boundary by water elevation time series at $4 \mathrm{~Hz}$ frequency. The model configuration used in this simulations were standard for regional configurations, see Table 1 for a description.

With this setting the 3D equations 1,2 and 3 , are solved without forcing terms $\left(\mathcal{F}_{u}=0\right)$. The vertical dissipation $\left(K_{M}\right)$ is set constant and the explicit horizontal eddy viscosity $\left(\mathcal{D}_{u}\right)$ is given by the flow- and resolution-dependent Smagorinski (SMAGORINSKI, 1963):

$v=\left(C_{s} \Delta x\right)^{2}|S|$

where $S$ is the strain rate, $\Delta$ the model resolution and $C_{S}$ the Smagorinsky constant. Such formulation allows to turn the dissipation on only when the shear becomes critical. 
An additional viscosity term $v_{b}$ is added to take into account the wave breaking, following the work done with Boussinesq models (KENNEDY et al., 2000), such as: $v_{b}=B \delta_{b}(h+\eta)$

where $\delta_{b}$ is a mixing length coefficient, $h$ and $\eta$ the reference water level and the elevation, and $\mathrm{B}$ a coefficient varying smoothly from 0 to 1 , depending on the slope.

For the bottom friction we use a logarithmic formulation, assuming that the flow in the bottom boundary layer has the classic vertical profile defined by a shear velocity $u_{*}$ and bottom roughness length $z_{0}$ as:

$|u|=\frac{u_{*}}{\mathcal{K}} \ln \left(\frac{z}{z_{0}}\right)$

with $|u|$ the module of the speed, $u_{*}$ is the friction velocity, $\mathrm{z}$ is the elevation above the bottom, $\mathcal{K}$ is von Karman's constant and $\mathrm{z}_{0}$ a constant bottom roughness length. The advantage of this approach is that the velocity and the vertical elevation of that velocity are used in the equation. Because the vertical elevation of the velocity in the bottom computational cell will vary spatially and temporally, the inclusion of the elevation provides a more consistent formulation.

Table 1. Model Setting

\begin{tabular}{ll}
\hline Model Parameters & Value \\
\hline Domain length & $30 \mathrm{~m}$ \\
Spatial resolution & $0.1 \mathrm{~m}$ \\
Number of vertical levels & 10 \\
Time step & $0.01 \mathrm{~s}$ \\
Vertical viscosity & $0.001 \mathrm{~m}^{2} \mathrm{~s}^{-1}$ \\
Smagorinsky constant & 0.01 \\
Bottom roughness & $0.001 \mathrm{~m}$ \\
\hline
\end{tabular}

\section{Results}

\subsection{Lidar measurements}

Lidar observations (water levels and topography) were compared with in situ measurements obtained by traditional techniques (pressure transducer for water levels and Real Time Kinematic GPS), in order to evaluate the accuracy of this novel remote sensing method. Results are presented in Figure 2 and show that wave observations performed by the Lidar have a very good correlation with correlation coefficient $\left(r^{2}\right)$ of 0.84 and root mean squared error (rmse) of about $0.1 \mathrm{~m}$. The results also show that Lidar observation tend to overestimate the observations performed by the PT, which is potentially due to the typical underestimation that PT have under very shallow water where a large amount of air mixed in the water perturbs pressure measurements. The comparisons made with the topographic observations (Figure 2) are significantly better, 


\section{XIV èmes Journées Nationales Génie Côtier - Génie Civil \\ Toulon, 29 juin au $1^{\text {er }}$ juillet 2016}

with an $r^{2}$ of 0.99 and rmse of $0.05 \mathrm{~m}$, which is an error in the order of the magnitude of the GPS accuracy $( \pm 5 \mathrm{~cm})$.
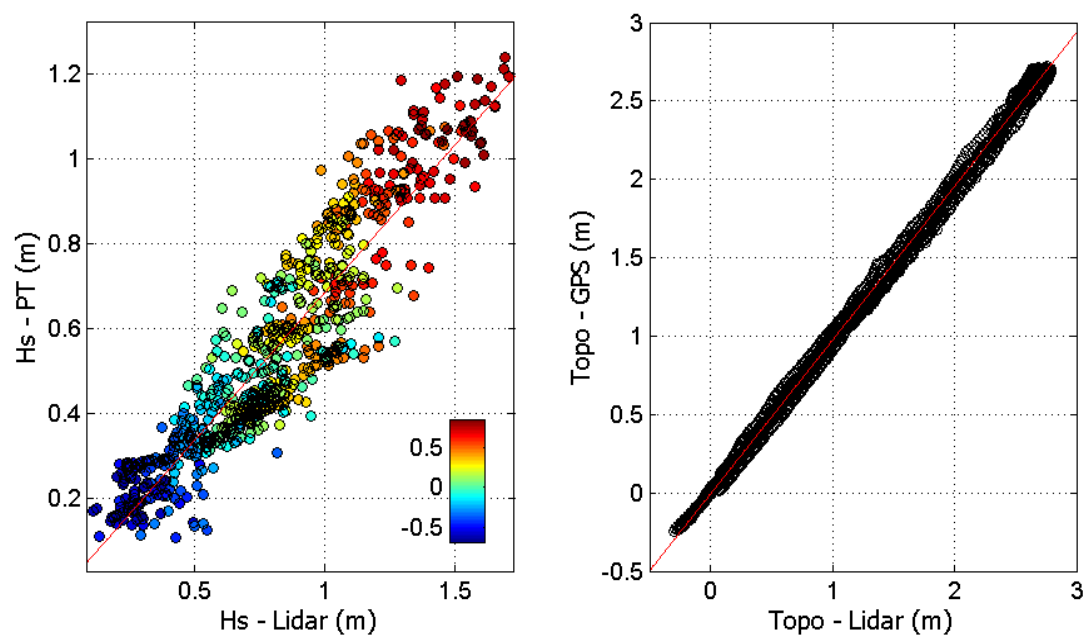

Figure 2. Comparison between significant wave height (Hs) measured by pressure transducer (PT) and Lidar (left figure); and scatter plot of the comparison between the topographic measurements performed by the RTKGPS and Lidar (right figure).

\subsection{Model test cases}

To assess the model results, we choose two samples of the data (10 minutes time series at $4 \mathrm{~Hz}$ ) that are presented in Figure 3. Case 1 represents an energetic wave conditions test, with long swell (12 s) and Hs of about $1.2 \mathrm{~m}$, while test case 2 represents a mild wind wave condition situation ( $\mathrm{Tp}<10 \mathrm{~s}$ and $\mathrm{Hs} \sim 1 \mathrm{~m}$ ). Figure 3 shows the Lidar time series used in these 2 test cases together with the offshore wave conditions and tides during the overall experiment. 

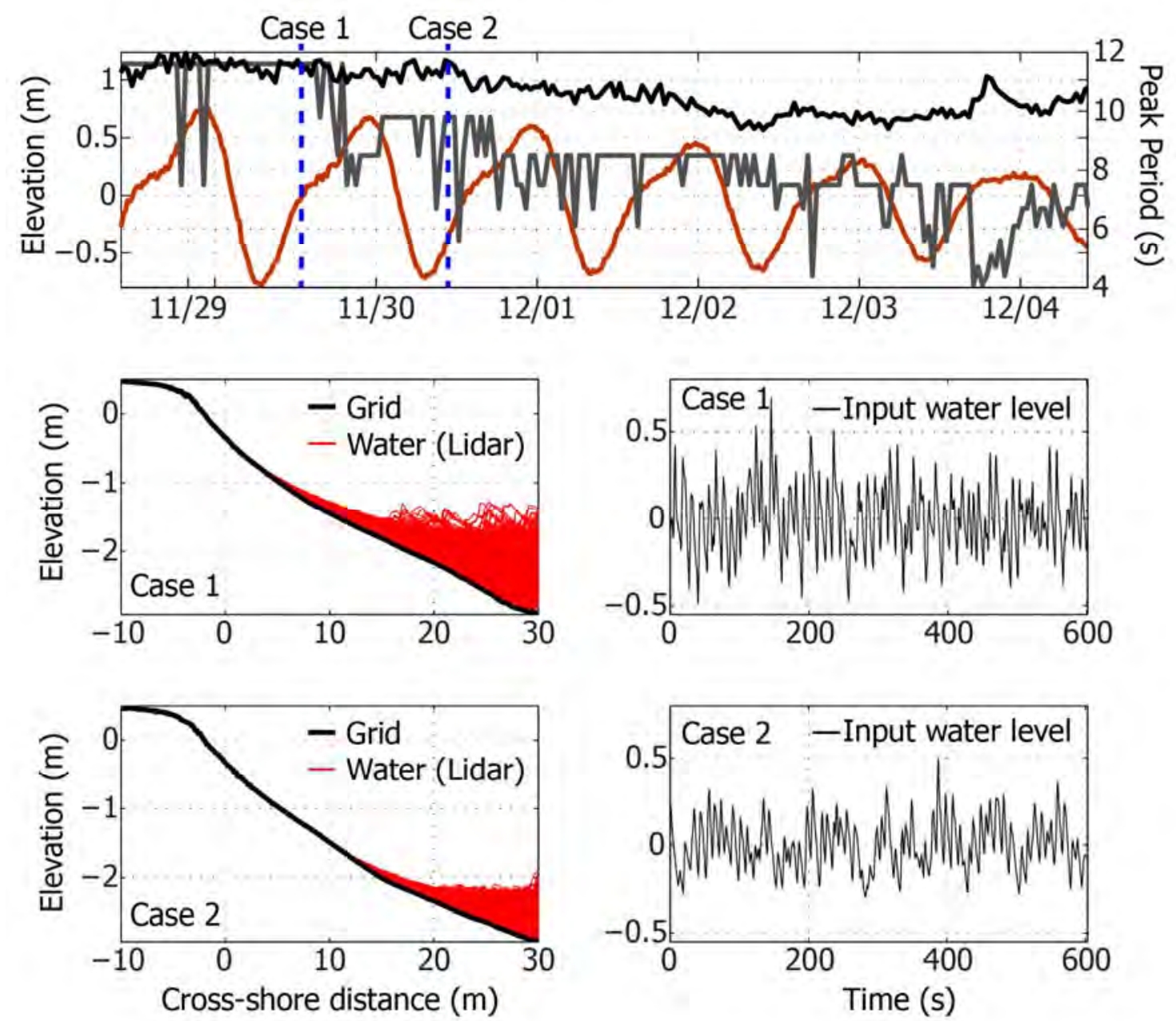

Figure 3. Offshore wave conditions and tides during the experiment (black line represents Hs, gray line is the Tp and brown line the tide) measured by a ADCP moored in $15 \mathrm{~m}$ depth (top panel); time series of water levels and topographic grid used in the two test cases (left panel) and time series of water elevations used as input in the offshore boundary of the model (right panel).

\subsection{Model results: wave-by-wave comparisons}

Model results were compared with field observations (Lidar) for the 2 test cases (Figures 4 and 5).

The model has been run with a threshold of $1 \mathrm{~cm}$ centimetre under which a cell is considered as dry (the outcoming mass flux is set temporarily to zero).

In both cases the model shows good agreement with the observation. Regarding the raw time series, in both cases, the model tends to miss several high frequency swash excursions, with predicted excursions showing smaller amplitude of variation compared with observations (Figure 4). In both test cases, swash excursion has an apparent larger duration in the model, which can be explained by an underestimation of the backwash 


\section{XIV èmes Journées Nationales Génie Côtier - Génie Civil \\ Toulon, 29 juin au $1^{\text {er }}$ juillet 2016}

velocity. Regarding wave setup and significant wave height, the discrepancy between model and observation at the offshore boundary can simply be explained by the model adjustment to accommodate a certain forcing water level but with zero velocity. The model overestimates those two quantities near the upper beach, indicating wave breaking acting too late.
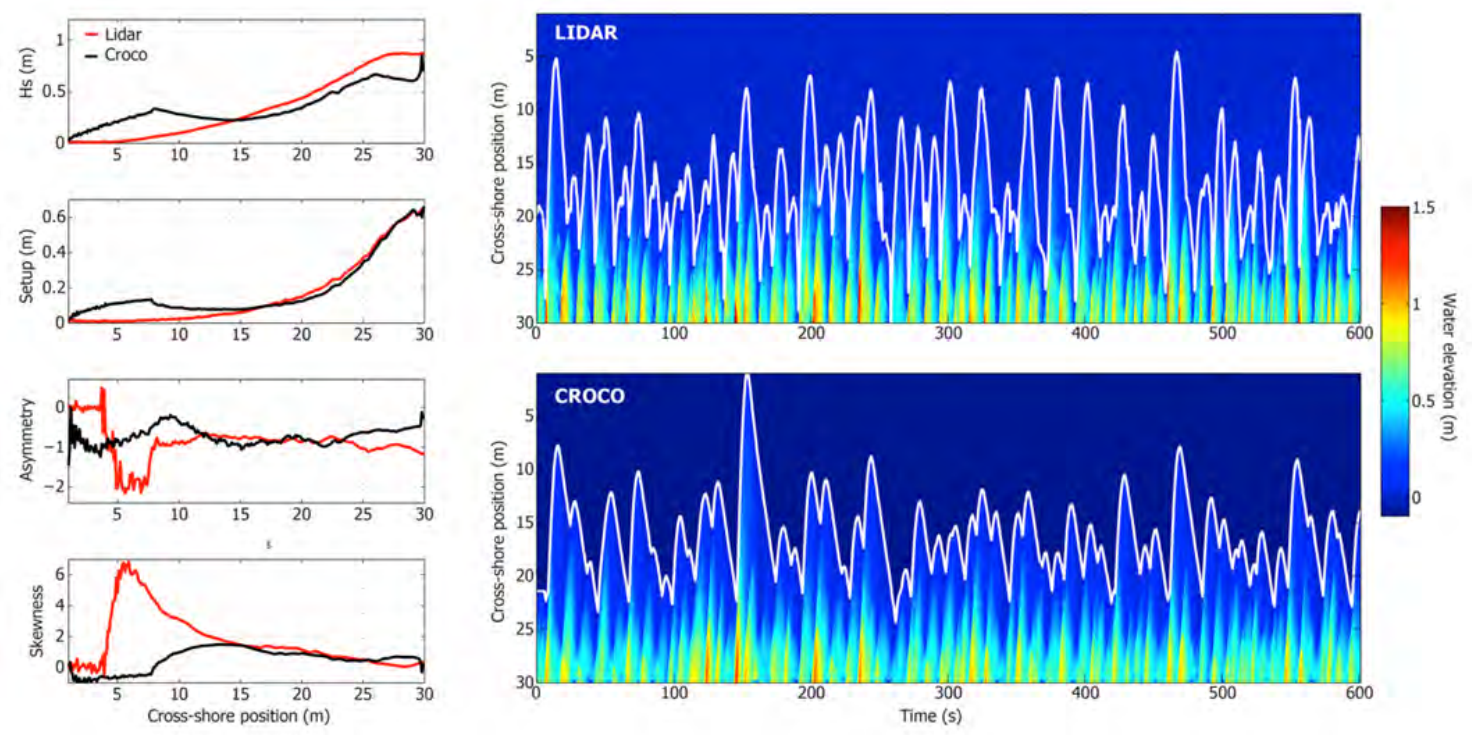

Figure 4. Model results for Case 1: comparison of statistical parameters (left panel); visual comparison between raw swash observations and predictions (right panel).
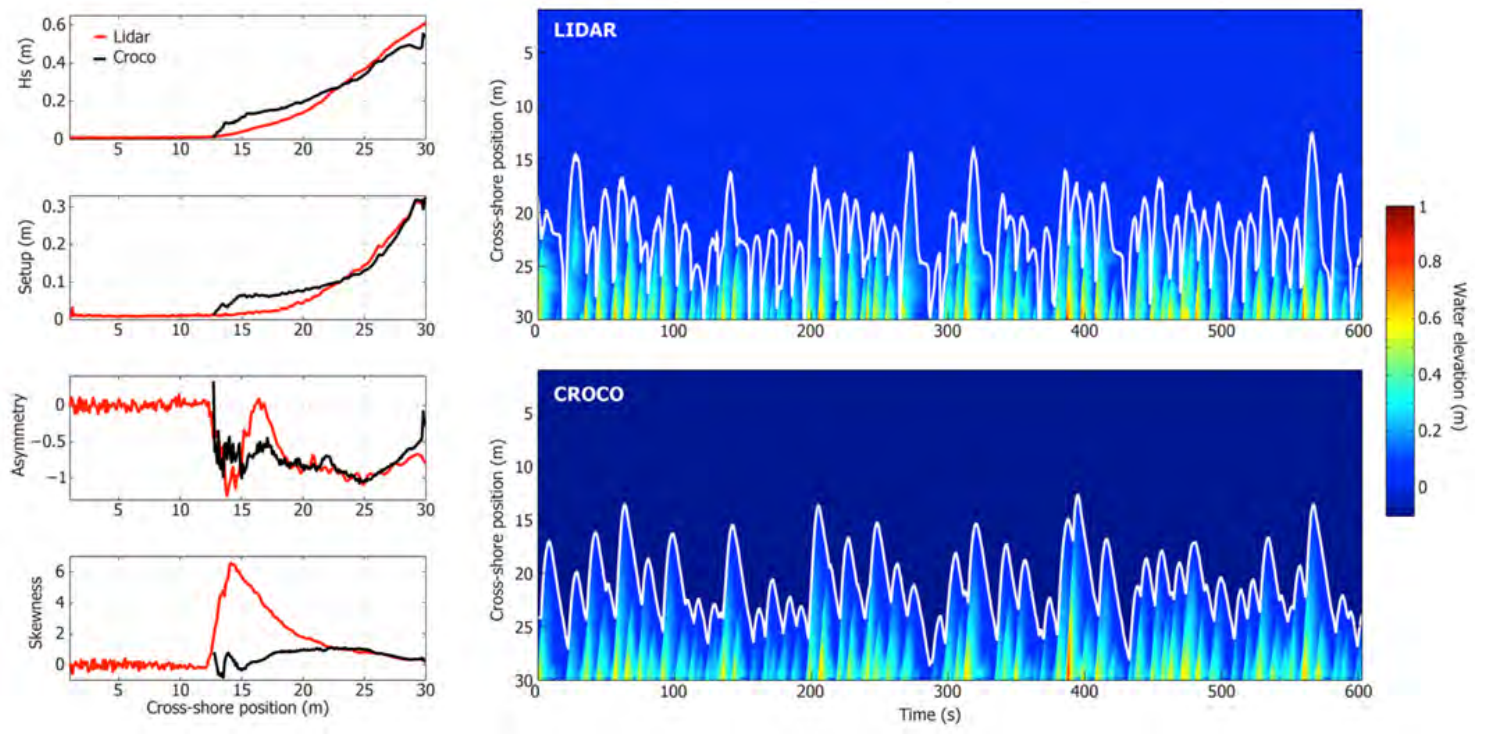

Figure 5. Model results for Case 2: comparison of statistical parameters (left panel); visual comparison between raw swash observations and predictions (right panel). 


\subsection{Model results: runup statistics}

Additional statistics were computed from model simulations and Lidar observations, such as the 2 and $10 \%$ exceedence of the runup (typical statistical parameter used in runup equations to characterize the extreme runup), together with the mean and maximum runup. The results are summarized in table 2 . The model seems to present a much better agreement with observations, particularly during the mild wave conditions (Case 2) for which the vertical runup statistics present small differences. Concerning energetic wave conditions (Case 1) most of the differences rise from the comparisons between the extreme runup parameters (e.g., R2\%, and Rmax) while the average (Rmean) runup elevation is predicted with a good level of accuracy.

Table 2. Run-up statistics.

\begin{tabular}{llllll}
\hline Date & Dataset & Rmax & Rmean & R2\% & R10\% \\
\hline 29/11/2015 & Lidar & -0.94 & -1.68 & 1.30 & 1.04 \\
\cline { 2 - 6 } (Case 1) & CROCO & -0.48 & -1.75 & 1.76 & 0.86 \\
\hline $30 / 11 / 2015$ & Lidar & -1.78 & -2.30 & 0.79 & 0.49 \\
\cline { 2 - 6 } (Case 2) & CROCO & -1.78 & -2.29 & 0.80 & 0.63 \\
\hline
\end{tabular}

\section{Conclusions and future work}

The ability of a tri-dimensional model (CROCO) originally suitable for regional circulation studies to reproduce swash zone motions (swash excursions and depth) was tested against novel measurements performed with a 2D Lidar. In the overall the model is performant in reproducing swash motions during mild and energetic wave conditions on a sandy beach with a fairly steep beach slope. While wave-by-wave comparisons indicate that the model underestimates backwash velocities and misses some higher frequency swash excursions, the runup statistics show that the model is capable of predicting mean and extreme runup elevations with a very high level of accuracy.

\section{Acknowledgments:}

This research has received support from grants by ANR (COASTWAR ANR-14ASTR-0019) and LEFE/INSU (COMODO-WAVES). It was also granted access to the HPC resources of GENCI-IDRIS under allocation 2014-017298

\section{References}

CHASSIGNET E.P., ARANGO H.G., DIETRICH D., EZER T., GHIL M., HAIDVOGEL D.B., MA C.-C., MEHRA A., PAIVA A.M., SIRKES Z. (2000). DAMEE-NAB: the base experiments. Dynamics of Atmospheres and Oceans, Vol. 32, pp 155-183. http://dx.doi.org/10.1016/\$0377-0265(00)00046-4 


\section{XIV ${ }^{\text {èmes }}$ Journées Nationales Génie Côtier - Génie Civil \\ Toulon, 29 juin au $1^{\text {er }}$ juillet 2016}

HAIDVOGEL D.B., ARANGO H.G., HEDSTROM K., BECKMANN A., MALANOTTE-RIZZOLI P., SHCHEPETKIN A.F. (2000). Model evaluation experiments in the North Atlantic Basin: Simulations in nonlinear terrain-following coordinates. Dynamics of Atmospheres and Oceans, Vol. 32, pp 239-281. http://dx.doi.org/10.1016/S0377-0265(00)00049-X

HAIDVOGEL D.B., ARANG H.G., BUDGELL W.P., CORNUELLE B.D., CURCHITSER E., DI LORENZO E., FENNEL K., GEYER W.R., HERMANN A.J., LANEROLLE L., LEVIN J., MCWILLIAMS J.C., MILLER A.J., MOORE A.M., POWELL T.M., SHCHEPETKIN A.F., SHERWOOD C.R., SIGNELL R.P., WARNER J.C., WILKIN J. (2008). Ocean forecasting in terrain-following coordinates: Formulation and skill assessment of the Regional Ocean Modeling System. Journal of Computational Physics, Vol. 227(7), pp 3595-3624. http://dx.doi.org/10.1016/j.jcp.2007.06.016

KENNEDY A.B., CHEN Q., KIRBY J.T., DALRYMPLE R.A. (2000). Boussinesq modeling of wave transformation, breaking, and runup. I: 1D. Journal of waterway, port, coastal, and ocean engineering, Vol. 126(1), pp 39-47. http://dx.doi.org/10.1061/(ASCE)0733-950X(2000)126:1(39)

MARCHESIELLO P. BENSHILA R. ALMAR R., UCHIYAMA Y., MCWILLIAMS J.C., SHCHEPETKIN A. (2015). On tridimensionnal rip current modeling. Ocean Modelling, Vol. 96, pp 36-48. http://dx.doi.org/10.1016/j.ocemod.2015.07.003

PENVEN P., DEBREU L., MARCHESIELlO P., McWILliAMS J.C. (2006). Evaluation and application of the ROMS 1-way embedding procedure to the central california upwelling system. Ocean Modelling, Vol. 12, pp 157-187. http://dx.doi.org/10.1016/j.ocemod.2005.05.002

SHCHEPETKIN A.F., MCWILLIAMS J.C. (2005). The regional ocean modeling system (ROMS): a split-explicit, free-surface, topography-following-coordinates ocean model. Ocean Modelling, Vol. 9, pp 347-404. http://dx.doi.org/10.1016/j.ocemod.2004.08.002

SMAGORINSKY J. (1963). General circulation experiments with the primitive equations. Monthly Weather Review, Vol. 91(3), pp 99-164. http://dx.doi.org/10.1175/15200493(1963)091<0099:GCEWTP>2.3.CO;2

WARNER J.C., SHERWOOD C.R., SIGNELL R.P., HARRIS C.K., ARANGO H.G. (2008). Development of a three-dimensional, regional, coupled wave, current, and sediment-transport model. Computers \& Geosciences, Vol. 34, pp 1284-1306. http://dx.doi.org/10.1016/j.cageo.2008.02.012 
Thème 1 - Hydrodynamique côtière 